\title{
Protection of Refugees By Their Country of Origin
}

\author{
Atle Grahl-Madsen $\dagger$
}

\section{Introduction}

Forty years after the Second World War, the international refugee crisis shows few signs of abating. Millions of persons continue to flee their states of nationality in search of safe havens, and the underlying conflicts in their home states that caused their flight often lack any hope of resolution. States of asylum are now realizing that their refugees may become long-term visitors. The refugees, for their part, fear their states of nationality and seek protection from their new home. International refugee law has proved slow to deal with the conflicts governments face as exiled citizens, still nominally "protected" by their home state, seek to adjust to their state of asylum. Refugee law must clarify the role that the state of nationality should play once a refugee has fled it.

This Article proposes a norm of international refugee law wherein the state of origin, by breaking its ties with a refugee, loses any right to "protect" or act on behalf of the refugee, until such time as the refugee willingly returns to that state. Part I offers a detailed definition and explanation of the concept of protection and the variety of activities it is often said to entail. Part II describes the position of the refugee as the quintessentially unprotected person. Part III outlines the role that protection plays in international law. It analyzes the interaction between nationality and protection and discusses the right of a state to protect its nationals both at home and abroad. Part IV looks back at the evolving notions of protection, emphasizing the shift from protection based upon residence to protection based upon formal requirements of nationality. The focus of the Article, the attempt by the state of nationality to assert its power over the refugee in his new residence, stems directly from the changing view of protection. Part V thus offers a new theory, emphasizing the irrelevance of a refugees's official nationality and proposing a legal ban on any protective measures by the state of origin.

$\dagger$ Professor of International Law, University of Bergen (Norway). 


\section{The Concept of Protection}

\section{A. Facets of Protection}

"Protection," like "asylum,"1 is a word of many facets. In treatises of international law, it is traditionally used to denote two types of state activities. First, it may refer to the practice whereby a state's diplomatic or consular agents take up foreign matters concerning that state's nationals-individuals or corporations-to ensure the rights and benefits guaranteed those individuals or corporations under general international law or international agreement. ${ }^{2}$ Second, protection is used to refer to a state's presenting of claims against another state alleging the latter's responsibility under international law for an injury suffered by an individual or a corporation of the former, in order to obtain reparation. ${ }^{3}$

Protection in these limited senses can be exercised for the benefit of only a small number of persons. The concept undoubtedly means more than this. Article 1(A)(2) of the Convention Relating to the Status of Refugees makes it a condition of refugee status that a person be "unable or ... unwilling to avail himself of the protection of [the country of nationality]."4 In this context, protection cannot have the traditional textbook meaning in which it is neither explicitly requested nor denied. Protection, therefore, consists partly of the opportunity to apply to the diplomatic or consular authorities representing one's home country for a passport or a certificate of citizenship. This type of document allows the holder to claim such benefits as a visa and a residence or work permit.

These arrangements, however, do not exhaust the range of measures falling within the general notion of protection. The Statute of the Office of the United Nations High Commissioner for Refugees (UNHCR) 5 enumerates many activities through which the High Commissioner shall provide for the protection of refugees. ${ }^{6}$ Most of these activities treat refugees collectively. They include efforts on behalf of refugees to promote new international agreements, to solicit general benefits for refugees, and

1. See 2 A. Grahl-Madsen, The Status of Refugees in International Law 3-7 (1972).

2. See E. Borchard, The Diplomatic Protection of Citizens abroad or The LAW OF INTERNATIONAL Claims 349-54 (1922).

3. Id.

4. Convention Relating to the Status of Refugees, opened for signature July 28, 1951, 189 U.N.T.S. 150, 152 [hereinafter cited as Convention on Status of Refugees]. The United States signed the Protocol Relating to the Status of Refugees on Jan. 31, 1967, 19 U.S.T. 6223, T.I.A.S. 6577, 606 U.N.T.S. 267, which entered into force Oct. 4, 1967.

5. 20 U.N. GAOR Supp. (No. 20) at 46; U.N. Doc. A/1775 (1950) [hereinafter cited as UNHCR Statute].

6. Id. para. 8. 
to maintain contact with governments as well as with various governmental, intergovernmental, and nongovermental organizations.

The term "protection" as currently used in international law in general, and in refugee law in particular, thus encompasses a broad spectrum of activities. These include:

-negotiating and concluding international agreements for the benefit of individuals and corporations;

-soliciting benefits for certain categories of persons;

- providing persons with documents enabling them to reap the benefits of agreements and other "deals" and arrangements between entities;

- taking up the case of persons against authorities of a foreign state either to ensure compliance with an agreement or a rule of general international law, or to claim for such persons some benefit, exemption, or privilege; and

- pressing claims for reparation, either restitution or indemnity, for injustice, inconvenience, or damage that a person has suffered and that may be directly or indirectly imputable to a foreign state, an international organization, or some other international actor.

The agency exercising protection will often, but not always, be a state. International organizations and organs may also exercise protection in certain circumstances. The Office of the United Nations High Commissioner for Refugees was created for the very purpose of protecting refugees. ${ }^{7}$ Even nongovernmental organizations and large corporations may exercise protection. Significantly, protected individuals or corporations need not be citizens or ressortissants 8 of the protecting state or other entity. The great number of international instruments pertaining to refugees bear witness to this fact. ${ }^{9}$ By international agreement, persons may even be protected against the state whose citizenship they possess. This possibility follows from the conventions and covenants protecting human rights and fundamental freedoms. ${ }^{10}$

7. Id. para. 1.

8. Ressortissants are "protected persons." See infra note 67.

9. A number of such instruments are reproduced in COLLECTION OF INTERNATIONAL INSTRUMENTS CONCERNING REFUGEES (2d ed. 1979) (UNHCR publication). See also infra notes $28,51,68,69$.

10. See, e.g., European Convention for the Protection of Human Rights and Fundamental Freedoms, Nov. 4, 1950, 213 U.N.T.S. 222; International Covenant on Civil and Political Rights, 21 U.N. GAOR Supp. (No. 16), at 52, U.N. Doc. A/6316 (1966); American Convention on Human Rights, Nov. 22. 1969, 36 O.A.S.T.S. 1., reprinted in R. LILLICH, INTERNATIONAI HUMAN RIGHTS INSTRUMENTS (1985). 


\section{B. Customary Protection: Diplomatic and Consular Protection}

Customary or traditional protection of individuals falls into two categories. Diplomatic protection signifies protection on a government-togovernment level. Such protection may be classified as general or particular. General diplomatic protection aims at improving conditions of persons at large through the negotiation and conclusion of general accords or specific agreements for citizens of the states concerned, for stateless persons, or for refugees. Particular diplomatic protection denotes measures undertaken to safeguard or advance the interests of particular individuals or corporations, as well as measures to press for reparations for wrongs suffered by any person claimed by the state to be a ressortissant of that state. The second type of customary protection, consular protection, is normally exercised at a lower level than diplomatic protection. ${ }^{11}$ Consular functions, outlined in the Vienna Convention on Consular Relations $^{12}$ and spelled out in more detail in the European Convention on Consular Functions, ${ }^{13}$ fall within the category of general protection.

\section{Contractual, International, and Nongovernmental Protection}

More novel modes of protection also exist. The notion of contractual protection ${ }^{14}$ derives from the rule of international law that every state party to a treaty has the right to ensure that all other parties fulfill their obligations in good faith. ${ }^{15}$ If the treaty or convention confers benefits upon individuals, ${ }^{16}$ each state may demand that other signatory states respect the rights given to individuals. States may even intervene to guarantee such rights. ${ }^{17}$

11. This characteristic may be obscured in cases where embassies also double as consulates-general.

12. Vienna Convention on Consular Relations, Apr. 24, 1963, 21 U.S.T. 77, T.I.A.S. No. 6820, 596 U.N.T.S. 261.

13. European Convention on Consular Functions, Dec. 11, 1967, Europ. T. S. No. 61 (has not yet come into force).

14. Contractual protection could also be called "conventional protection" in the sense of protection based on a treaty or convention. However, since the term "conventional protection" could be misinterpreted as traditional protection, "contractual protection" is preferable.

15. See $1 \mathrm{~L}$. OPPENHEIM, INTERNATIONAL LAW 877-81 (H. Lauterpacht 8th ed. 1955) (discussion of pacta sunt servanda, binding force of treaties) [hereinafter cited as L. OPPENHEIM \& H. LAUTERPACHT].

16. See, e.g., Convention on Status of Refugees, supra note 4, and human rights conventions cited supra note 10.

17. Related to this aspect of state action is the protection of residents, such as resident refugees, which states may exercise by express agreement or through informal understandings with other states. See, e.g., European Convention on Consular Functions, supra note 13. 
International protection is protection exercised by an international organ or organization for individuals under its mandate. ${ }^{18}$ Such protection may be based on explicit convention provisions, such as article 35 of the Convention on the Status of Refugees, ${ }^{19}$ or on other grounds, such as provisions of the UNHCR Statute ${ }^{20}$ or resolutions of the United Nations General Assembly. ${ }^{21}$ A special type of international protection, exercisable by organizations on behalf of their agents, was described in the advisory opinion of the International Court of Justice in the Bernadotte case. ${ }^{22}$ Finally, actions amounting to protection may be taken by nongovernmental organizations, notably voluntary humanitarian agencies, and even by corporations. ${ }^{23}$ These activities, variously defined as virtual protection, quasi-protection or protection-like activities, fall under the heading of "nongovernmental protection."

\section{Protection vs. Assistance}

International protection must be distinguished from international assistance. Protection suggests a tripartite relationship: one party protects a second against either a third party or forces of nature. Assistance, on the other hand, denotes a bilateral relationship between a provider and a recipient. Though in principle the distinction is clear, in practice borderline cases often arise. If a resident or visiting alien encounters difficulties with territorial authorities, he may appeal for the protection of his country's local consul. If the alien is penniless, he may approach the consul for assistance, in the form of a ticket home. If, for example, he has lost a passport and turns to the consul for a new one, the consul's response could entail both protection and assistance. When an alien requires a passport to obtain a residence permit or to leave the country, the issuance of an emergency passport or other document may be interpreted as a request that the territorial authorities allow the person to stay or to

18. This is "legal and political protection" in the parlance of the International Refugee Organization (IRO). See L. HolboRN, THE INTERNaTional RefugeE ORGanization: A SPECIALIZED AgENCY OF THE UNITED NATIONS, ITS HISTORY AND WORK 1946-1952, at 311-28 (1956).

19. See supra note 4.

20. See supra note 5, para. 8(c)-(h).

21. See generally U.N. Resolutions and Decisions relating to the Office of the United Nations High Commissioner for Refugees, U.N. Doc. HCR/INF. 48/Rev. 3 (1983).

22. Reparations for Injuries Suffered in the Service of the United Nations, 1949 I.C.J. 1 (Advisory Opinion of Apr. 11). Count Bernadotte was murdered while carrying out his duties as United Nations Mediator in Palestine. The General Assembly asked the I.C.J. for an Advisory Opinion on the capacity of the U.N. to bring an international claim against the responsible government to obtain reparations for injuries suffered in the service of the U.N. The Court upheld such a capacity both for injuries to the U.N. and to individuals. Id. at 187.

23. S. Aiboni, Protection of Refugees IN Africa 111-19 (1978). 
leave without hindrance. This represents a protective measure. But if, as in Denmark and Sweden, there is no official control over departing aliens, ${ }^{24}$ the issuance of a passport serves primarily to allow the bearer to enter his own country unimpeded. This more closely resembles a case of assistance, since the relationship involves only the issuing state and its citizen. The same result could have been achieved through a telephone call or telex message from the consul to his country's immigration service. The gray area between assistance and protection becomes apparent in the context of a typical refugee situation, involving the provision of care and sustenance in a refugee camp. Such care clearly constitutes assistance, as it involves a bilateral act between the providing agency and the refugee. Yet, to provide this assistance, an international organ such as the UNHCR may first have to negotiate an agreement with territorial authorities and then obtain permission to admit the refugee to the camp. These negotiations are embraced by the notion of protection. Furthermore, when local authorities near a refugee camp learn of an agency's interest in the person, they may wish to aid in dispensing benefits. Commonly, these authorities want to maintain a positive relationship with such agencies; hence, the agencies have leverage to intervene on behalf of affected persons. What is designed as an assistance measure may thus have protective effects.

\section{E. Passports and Protection}

According to one traditional view, a passport is "a document of identity issued by a state, ordinarily to its own nationals, which requests foreign governments to grant the bearer safe and free passage and all lawful aid and protection while within their jurisdiction, and implicitly guarantees that they will be readmitted to the issuing country."25 This description offers little guidance in practical terms. A passport need not necessarily be issued by a state; it is not always trustworthy as an identity document or proof of citizenship; and it does not always contain an explicit request to foreign governments. ${ }^{26}$ It does, however, implicitly guarantee the readmittance of the bearer to the territory of the issuing (state) authority.27 A passport could be all the things suggested in the above description, but it need not be any of them.

24. Only a routine airport security check is performed.

25. D. TuRACK, The PASSPORT IN INTERNATIONAL LAW 15 (1972) (quoting CANADIAN DEPT. OF EXTERNAL AfFaIRS, EXTERNAL AfFairs (1953)).

26. British and American passports do contain such a request for protection.

27. See infra note 29 and accompanying text. There are passports that do not allow the bearer to enter the territory of the issuing state. This applies to some British passports and also to certain passports issued by the Republic of China in Taiwan to Chinese not resident on 
Foreign governments generally require that aliens admitted or allowed to stay in their territories possess a passport or some other recognized travel document. ${ }^{28}$ A government may be less inclined to admit foreigners if it cannot oust them when it deems necessary. Under international law, a state must readmit its citizens to its territory at the request of a foreign government; ${ }^{29}$ however, if a foreigner is admitted without any papers, or with an identity card alone, he may be returned to the country of which he is a citizen only if his citizenship is undisputed or can be proved by the returning state. If, on the other hand, he is admitted on the strength of a national passport, his citizenship is presumed, and the issuing state is obliged to readmit him throughout the period his passport is valid and for a short while beyond. The issuing state can refuse admission only if it can prove that the bearer is actually the citizen of another state. Thus, issuance of a passport shifts the burden of proving citizenship onto the issuing state.

While a passport is an eminently practical document, it possesses a mystique all its own. According to Borchard, the United States government insists that foreign governments treat an American passport as prima facie proof of American citizenship. ${ }^{30}$ American authorities expect that bearers of American passports be given all the rights and benefits to which American citizens are entitled in a foreign country, unless authorities can show cause for not accepting the bearer's American citizenship. A foreign government that admits a foreigner on the strength of an American passport risks intervention by United States diplomatic or consular services if it does not treat the foreigner as American authorities expect Americans to be treated. A similar significance is attached to the passport in many, if not most, states. ${ }^{31}$

the island. See Young v. Bundesrepublik Deutschland, BVerwG IC 138.60, Mar. 23, 1964, cited in 1 A. Grahl-MadSEN, The Status of Refugees in INTERnational LaW 191 (1966).

28. In this role, the ordinary national passport competes with other documents, such as refugee travel documents and laissez-passes. See Resolution of the Third General Conference on Communication and Transit, LEAGUE of NATIONS O.J. Spec. Supp. 54, at 201 (1927); Convention Relating to the Status of Stateless Persons, Sept. 28, 1954, art. 28 with Schedule, 360 U.N.T.S. 117, 152 (entered into force June 6, 1960) [hereinafter cited as Convention on Stateless Persons]; Convention on Status of Refugees, supra note 4, art. 28 and Schedule. Between a number of the member states of the Council of Europe, domestic identity cards are accepted in lieu of passports. Citizens of the Nordic states may even travel and reside throughout the North without any papers at all.

29. P. Weis, Nationality and Statelessness in INTERNational LaW 50 (1956).

30. E. BORCHARD, supra note 2, at 493.

31. Although the French government does not insist that a person with dual citizenship, where one of the citizenships is French, enter France only on the strength of his French passport, once the person is in France his French passport is used as evidence that the person is a Frenchman and not a foreigner, and it is presumed that no foreign government has standing to 
Issuing or renewing a passport thus often amounts to an act of protection, as in the famous British case of William Joyce, known as "Lord Haw Haw," 32 which turned on the accused's possession of a British passport. Joyce, an Irishman, falsely declared himself "a British subject by birth," thus acquiring a British passport in 1933.33 The passport was renewed for one year in 1938 and again in 1939. With the outbreak of World War II, Joyce left Britain for Germany, where he gained notoriety as an anti-British broadcaster. At the end of the war, he was arrested in Germany and brought to trial in England for treason. The Crown contended, and the court agreed, that anyone holding a British passport, even if wrongfully acquired, owes allegiance to the Crown while the passport remains valid, whether or not that person is physically present in the United Kingdom. The court declared that by applying for and using a British passport, an alien has clothed himself with the status of a British subject. ${ }^{34}$ Because possession of a British passport entitles the alien to the protection of British consular offices, "protection draws allegiance." 35

Because of their role in protection, passports can be important in determining the status of refugees. ${ }^{36}$ Possession of a passport may negatively affect a refugee's status in international law. A refugee is, by definition, unwilling or unable to avail himself of the protection of the country of his nationality. ${ }^{37}$ If he "reavail[s] himself of the protection" of his country, he ceases to be a refugee. ${ }^{38}$ Acquisition of a passport has been considered adequate for "reavailing oneself of protection."

Some countries of refuge strictly apply two rules to passport acquisition by refugees. First, a person applying for refugee status must surrender his national passport. Second, a refugee who acquires a new passport or renews an old one loses refugee status. Switzerland, in particular, has stressed these rules. Certain other countries apply them less rigidly or not at all. For many years, Sweden required refugees to keep and renew their passports, so that Swedish residence permits could be

protect him against the French government. Telephone interview with Jean-Claude Bouvard, Deputy Consul and Chief of Chancellery, French Consulate of New York (Apr. 24, 1986).

32. Joyce v. Director of Public Prosecutions, 1946 A.C. 347 (H.L.).

33. Id. at $348-49$.

34. The court stated that "the possession of a passport by one who is not a British subject gives him rights and imposes upon the sovereign obligations which would otherwise not be given or imposed." Id. at 369.

35. Id. at 366-68.

36. See 1 A. GRAHL-MADSEN, supra note 27, at 379-92.

37. See, e.g., Convention on Status of Refugees, supra note 4, art. 1(A)(2).

38. Id. art. $1(C)(1)$. 
stamped in them. ${ }^{39}$ The Swedish practice, which has since been abandoned, proved problematic, as it forced refugees to maintain contact with the consular agents of the regime from which they had fled. The Swiss practice corresponds more closely to the intentions of the drafters of the Convention on the Status of Refugees, and has since become the general practice. ${ }^{40}$ While it does not lend itself to obvious criticism, it does not address the intrinsic character of passports and their relation to protection in general. While the passport plays an important role in diplomatic and consular protection, it is only a prima facie proof of citizenship. The real test of citizenship in most states, including the United States, is whether the bearer actually possesses the nationality of the state that purports to protect him, and from whose protection he is not excluded due to dual citizenship or refugee status. Just as the possession of a passport is not sufficient for the exercise of active protection, it is also not necessary. A state may protect a citizen whether he has no passport, never possessed one, or even if he possesses a passport issued by some other state or agency.

Nevertheless, there remains some merit to the view that a passport represents a request, albeit tacit, to foreign governments that they treat the bearer as the government of the issuing state would like to see its citizens treated. If a passport is issued and recognized in this spirit, its issuance may very well be considered a measure of protection. On the other hand, if its purpose is merely to enable a person to comply with the formal requirements of the alien and immigration laws of a particular state, and if this is clearly understood by all concerned, the issuance of the passport will have little to do with protection in a more profound sense. Instead, those involved will perceive it as merely a practical document issued for practical purposes. ${ }^{41}$

\section{Refugees as Unprotected Persons}

The denial of diplomatic protection by one's country of origin is the crucial characteristic of refugee status. ${ }^{42}$ When France passed a law relating to foreign refugees in 1832,43 the French Garde des Sceaux explained in the National Assembly that refugees were foreigners staying in

39. See G. Melander, Flyktingar och ASyl 140 (1972).

40. See Convention on Status of Refugees, supra note 4, art. 1; Protocol Relating to the Status of Refugees, supra note 4, art. 1.

41. Sweden held this view at one time, although it is unclear how widespread the view is currently. See G. MELANDER, supra note 39 , at 151-52.

42. See supra note 37 and accompanying text.

43. Loi relative aux Etrangers réfugiés qui residéront en France, 87 Bull. Des Lois 192 (Fr. 1832). 
France without a passport and without the protection of their own governments. ${ }^{44}$ The denial of protection by the refugee's country of origin appeared as a prominent criterion in all definitions of refugee adopted between the two world wars. For example, a 1926 arrangement ${ }^{45}$ defined a Russian refugee as "[a]ny person of Russian origin who does not enjoy or who no longer enjoys the protection of the Government of the [U.S.S.R.] and who has not acquired another nationality." 46 The definition, in an arrangement of 1928 of Assyrian, Assyro-Chaldean, and "assimilated" refugees ${ }^{47}$ proposes the same idea in a more generalized form: a refugee is one "who does not enjoy or who no longer enjoys the protection of the State to which he previously belonged and who has not acquired or does not possess another nationality."48 Only the Plan for the Issue of a Certificate of Identity to Refugees from the Saar of May 24,

44. 32 J. Duvergier, Collection Compléte des lois, Decréts, Ordannances, REGLEMENTS ET AVIS DU CONSEIL D'ETAT [Duv. \& Boc.] 167 n.2 (1832) ("ceux qui, sans passeport, sans relation avec aucune espèce d'ambassadeur . . . ."); 1 A. GRAHL-MADSEN, supra note 27, at 95 . Note that this was two years after the 1830 revolution in France and a year after a Polish uprising had been crushed by the Russians at Ostrolenka in 1831, which caused many Poles to flee to France.

45. Arrangement Relating to the Issue of Identity Certificates to Russian and Armenian Refugees, May 12, 1929, 89 L.N.T.S. 47.

46. Id. at 49. An Armenian refugee was similarly defined in 1926 as "[a]ny person of Armenian origin formerly a subject of the Ottoman Empire who does not enjoy or who no longer enjoys the protection of the Government of the Turkish Republic and who has not acquired another nationality." Id. See 1 A. GRAHL-MADSEN, supra note 27, at 122-27. Note that according to these definitions, a refugee from the Russian part of Armenia would qualify as a "Russian," not as an "Armenian" refugee.

47. Arrangement Concerning the Extension to Other Categories of Refugees of Certain Measures Taken in Favour of Russian and Armenian Refugees, June 30, 1928, 89 L.N.T.S. 65.

48. Id. at 65. See 1 A. GRAHL-MADSEN, supra note 27, at 127-28. The definitions of "Austrian refugees" and "refugees from Sudetenland" were basically designed in the same way. See Refugees Coming from the Territory which Formerly Constituted Austria, June 4, 1938, 19 LEAGUE OF NATions O.J. 646; International Assistance to Refugees coming from Territories Ceded by Czechoslovakia to Germany, Jan. 17, 1939, 20 LEAGUE OF NATIONS O.J. 72. See also Draft Protocol Proposed by the United Kingdom of Great Britain and Northern Ireland, Sept. 2, 1938, 19 League of Nations O.J. 678; Additional Protocol, July 14, 1939, 20 League of NATions O.J. 375; Additional Protocol, Sept. 14, 1939, 198 L.N.T.S. 141. The Convention Concerning Refugees Coming from Germany propounded the traditional definition:

a) persons possessing or having possessed German nationality and not possessing any other nationality who are proved not to enjoy, in law or in fact, the protection of the German Government;

b) Stateless persons not covered by previous Conventions or Agreements who have left German territory after being established therein and who are proved not to enjoy, in law or in fact, the protection of the German Government.

Convention Concerning Refugees Coming from Germany, Feb. 10, 1938, 192 L.N.T.S. 59, 63 [hereinafter cited as 1938 Convention]. The definition also contained the provision that "[p]ersons who leave Germany for reasons of purely personal convenience are not included in this definition." Id. A post-war French decree similarly defined Spanish refugees. Decree No. 45-766, Mar. 15, 1945, 1945 Journal Officiel de la République Française [J.O.] 2254, cited in 1 A. GRAHL-MADSEN, supra note 27, at 131. 
$1935^{49}$ contains no direct reference to the denial of state protection as a requirement for refugee status. The implication is the same, however, since the conditions for recognition as Saar refugees were that, "having previously had the status of inhabitants of the Saar, [they] have left the territory on the occasion of the plebiscite and are not in possession of national passports." 50

The Constitution of the International Refugee Organization (IRO) ${ }^{51}$ created definitions of "refugee" and "displaced person" for a specific purpose-to determine eligibility for the services of that organization. 52 The IRO definition of "refugee" includes all persons who were considered refugees before the outbreak of World War II, but there is no explicit reference to a denial of state protection. However, the notion of "victims" of a given regime, a forerunner of the notion of "persecution," appears here as a criterion of refugee status. ${ }^{53}$

The requirements of a "well-founded fear of persecution" and a denial of state protection are combined in paragraph 6 of the UNHCR Statute, which defines the High Commissioner's competence ratione personae, ${ }^{54}$ and again in Article 1(A)(2) of the Convention on the Status of Refugees. ${ }^{55}$ Both instruments make it a condition of refugee eligibility that the person in question be "unable or . . . unwilling to avail himself of the protection of [the country of his nationality]." 56 For stateless persons, this condition is supplanted by the requirement that such person be "un-

49. 16 LEague of NATions O.J. 1681 (1935) [hereinafter cited as Plan for Refugees from the Saar].

50. Id. By a plebiscite under the supervision of the League of Nations, a great majority of the inhabitants of the Saarland had opted for integration into Germany. Until the plebiscite, the Saar territory had been provisionally administered by an international commission under the Treaty of Versailles. See Treaty of Peace with Germany, June 28, 1919, part III, annex to arts. 45-50, chs. II-III. The refugees were those who left the territory either because they did not want to become German nationals or because they feared the Nazi regime established in Germany. French citizens could qualify for French passports and consequently were not included in the definition. See 1 A. GraHL-MADSEN, supra note 27, at 132.

51. Constitution of the International Refugee Organization, opened for signature Dec. 15, 1946, 18 U.N.T.S. 3 [hereinafter cited as IRO Constitution].

52. This is how the word "eligibility" came into refugee law parlance. We now speak about "eligibility" for refugee status, which may sound peculiar if one does not know the historical origin of the word.

53. See IRO Constitution, supra note 51, part 1, sec. A. See also 1 A. GRAHL-MAdSEN, supra note 27, at 134-35.

54. See supra note 5. Exclusion clauses are contained in paragraph 7 of the UNHCR Statute.

55. See supra note 4. Article 1(A)(1) relates to "statutory refugees," meaning refugees according to previous international instruments. Id.

56. Convention on Status of Refugees, supra note 4, art. 1(A)(2). See also 1 A. GRAHLMADSEN, supra note 27, at 254. 
able or . . . unwilling to return [to the country of his former habitual residence]." 57

According to these modern definitions, unwillingness to avail oneself of protection must stem from a well-founded fear of persecution based on race, religion, national origin, membership in a social group, or political opinion. ${ }^{58}$ Inability to avail oneself of protection is not subject to such a proviso. However, since a refugee must be outside his country of origin because he fears his fate there, the criterion of inability to avail oneself of protection incorporates the notion of persecution. A person may be unable to avail himself of protection for the following reasons:

-protection may be refused expressly or tacitly, as when a passport is denied or even cancelled;

-the government of the country of origin may not be recognized by the government of the country of refuge; and ${ }^{59}$

- the two countries may be at war with each other. ${ }^{60}$

Denial of protection thus proved to be the distinguishing feature of the earliest definitions of "refugee." These definitions were ad hoc in nature and applied to persons who had left specific countries as a result of political upheavals and repressive governmental policies. Since the international community was generally aware of repression in such countries, it was unnecessary to expound on this denial of protection in the definitions. The salient point was that the person concerned was not in good standing with the new government of his home country, and the concept of denial of protection came to express this idea. However, the generalized definition of refugee in the post-World War II instruments failed to explain why persons would be outside their country of origin. Hence, the notion of well-founded fear of persecution for certain enumerated

57. Convention on Status of Refugees, supra note 4, art. 1(A)(2).

58. Convention on Status of Refugees, supra note 4, art. 1(A)(2); UNHCR Statute, supra note 5 , para. $6(\mathrm{~A})(\mathrm{ii})$.

59. In discussing the situation of Chinese refugees in Hong Kong, Hambro maintains that most were not unwilling to avail themselves of the protection of the Taiwan government, which at the time occupied the Chinese seat at the U.N. E. HAMBro, The Problem of ChINESE Refugees IN HoNg KoNg 35 (1955). However, he overlooks the fact that, because of the British government's shift of recognition from the Taiwan to the Chinese government, these refugees were unable to avail themselves of such protection. See also 1 A. GRAHL-MADSEN, supra note 27 , at $258-59$.

60. There are additional but less relevant reasons for lack of protection. The actual means of providing protection may be lacking, as when diplomatic relations or consular services are lacking. Yet, usually, if the person desires protection, the government is willing to provide it, and it has the physical means for doing so, it is hard to envisage the person in question as a refugee. See Convention on Status of Refugees, supra note 4, art. 1(C)(1); see also 1 A. GRAHL-MADSEN, supra note 27, at 379-81. 
reasons evolved and supplemented the time-honored notion of denial of protection.

The stipulation in the various definitions that a denial of state protection constitutes a criterion of refugee status has given rise to the notion of "unprotected persons," persons without traditional or customary diplomatic and consular protection. Stateless persons have been categorized as "de jure unprotected persons," as distinguished from "de facto unprotected persons,"61 who are refugees formally possessing the nationality of their country of origin. However, the designation of refugees as de facto unprotected persons begs the question of whether the country of origin has a right in international law to protect those nationals who have left the country as refugees. If this critical question is answered in the negative, refugees, whether stateless or formally possessing a nationality, are truly de jure unprotected persons, and to identify them as merely. de facto unprotected persons would be misleading. ${ }^{62}$

The definitions of "refugee" in the 1920's spoke merely of a denial of state protection, but definitions adopted throughout the 1930's concerning German, Austrian, and Spanish refugees added to that requirement the words "in law or in fact."63 The reason for introducing this distinction between de jure and de facto lack of protection remains unclear. Apparently the phrase "in law or in fact" was no more than a cautious addition to prevent persons from being denied refugee status on the basis of a theoretical argument as to whether their lack of protection was legally or merely factually based. ${ }^{64}$ Neither the UNHCR Statute nor the Convention on the Status of Refugees addresses this question. ${ }^{65}$ Rather, these conventions emphasize the situation and attitude of the individual: he may be recognized as a refugee if he is unwilling or unable to avail himself of the protection of the country of his nationality. The modern conception of refugee status has thus helped terminate the obsolete and

61. See Weis, Legal Aspects of the Convention of 25 July 1951 Relating to the Status of Refugees, 30 BRTT. Y.B. INT'L L. 480 (1953); 1 A. GRAHL-MADSEN, supra note 27, at 96.

62. See 1 A. GRAHL-MADSEN, supra note 27, at 97-101.

63. See, e.g., 1938 Convention, supra note 48 , art. I(1)(a).

64. The distinction could have come from the view that a person being denationalized was considered unprotected in law, whereas those refugees who had formally retained their nationality were considered unprotected in fact. Yet, this explanation is contradicted by the fact that the "in law or in fact" expression is used in the 1938 Convention, supra note 48 , not only with respect to "persons possessing or having possessed German nationality," but also to "stateless persons," apparently including such stateless persons who never possessed German nationality. Id. art. I(1)(a)-(b). It is neither warranted nor decisive to read any particular construction into the distinction with respect to the right exercised by the country of origin in the 1938 Convention and the 1939 Protocol. Additional Protocol, opened for signature Sept. 14, 1939, 198 L.N.T.S. 141.

65. See Convention on Status of Refugees, supra note 4; UNHCR Statute, supra note 5. 
merely theoretical difference between de facto and de jure protected persons.

Indeed, both early refugee groups and post-war refugees share the experience of the disruption or non-existence of the normal bond of trust and allegiance between citizen and government, leaving a relationship of fear and alienation. Such disruption transcends the label de jure or de facto. As Kimminich first pointed out, a politically motivated breach of the bond between government and individual defines the latter as a refugee. 66 The denial of state protection is actually a symbol or a manner of speech to describe the broken bond. Denial of protection is, in fact, a symptom rather than the disease itself.

\section{The Role of Customary Protection in International Law}

\section{A. The Link Between Nationality and Protection}

Public international law recognizes that the question of a person's status as a national or citizen ${ }^{67}$ of a given state should be determined according to the laws of that state. ${ }^{68}$ As nationality laws vary considerably from state to state and no agreement on any general international convention with respect to nationality has yet been reached, some persons may be considered nationals of two or more states, while others may not qualify as nationals of any state. ${ }^{69}$

Refugees may be stateless or they may have retained their formal nationality. ${ }^{70}$ In some cases, ascertaining nationality may be difficult. For example, the government of the Soviet Union refused to consider as

66. O. Kimminich, Der Internationale Rechtsstatus Des FlÜchtlings $33-48$ (1962).

67. The words "national," "subject," and "citizen" are used synonymously here, meaning a person possessing the nationality (citizenship) of a particular State. Additionally, it is not essential to make a distinction between "citizens" and so-called "protected persons" or "ressortissants." See generally P. WEIs, supra note 29, at 3-7; 1 L. OPPENHEIM \& H. LAUTERPACHT, supra note 15, at 644-45.

68. See Convention on Certain Questions Relating to the Conflict of Nationality Laws, Apr. 12, 1930, 179 L.N.T.S. 89 [hereinafter cited as Convention on Conflict of Nationality Laws]. Article 1 provides that "[i]t is for each State to determine under its own law who are its nationals. This law shall be recognised by other States in so far as it is consistent with international conventions, international custom, and the principles of law generally recognised with regard to nationality." Id. at 99 . See P. WEIS, supra note 29, at $65 ; 1 \mathrm{~L}$. OPPENHEIM \& H. LAUTERPACHT, supra note 15, at 642-43.

69. See $1 \mathrm{~L}$. OPPENHEIM \& H. LAUTERPAChT, supra note 15, at 664-65; P. WEIS, supra note 29, at 165; Convention on Stateless Persons, supra note 28, art. 1(1) ("For the purpose of this Convention, the term 'stateless person' means a person who is not considered as a national by any State under the operation of its law.").

70. See UNHCR Statute, supra note 5, para. 6(A)(ii); Convention on Status of Refugees, supra note 4, art. I(A)(2); Lov om utlendingers adgang til riket $m$. v. (Norwegian Aliens Act), $\S 2$, July $27,1956$. 
Soviet citizens those refugees who fled the country following the Russian revolution. ${ }^{71}$ However, the U.S.S.R. strongly maintained that persons "displaced" during and after World War II were Soviet citizens requiring repatriation. Generally, refugees in the post-war period are considered to possess the formal nationality of their country of origin. Their children born abroad will often be awarded "uncertain" or "undecided" status.72 Thus, to say that a refugee is a national of his country of origin ${ }^{73}$ simply means that he is considered a national according to its laws. In relation to that country, he may have, at least nominally, such rights and duties as its municipal law attaches to the possession of its nationality or citizenship. ${ }^{74}$ Such a status could result in serious domestic consequences if he ever returns or otherwise falls into the hands of authorities of that country, as, for example, during a military occupation..$^{75}$ The legal relationship between the state and its nationals is a complex municipal law issue, particularly since the relationship differs from country to country.

In international law, nationality has two major effects: a state may protect its nationals vis-à-vis other states, and it has a duty to readmit them to its territory should another state decide to expel them. ${ }^{76}$ Commissioner Nielsen in the Naomi Russell Case ${ }^{77}$ aptly stated that "[n]ationality is the justification in international law for the intervention of one government to protect persons and property in another country."78 While nationality is not always necessary or sufficient for protec-

71. See Raestad, Statslфose personer og deres rettsstilling, 5 NoRDISK TIDSSKRIFT FOR INTERNATIONAL RET 177, 185 (1934).

72. Id. at 182 (Norwegian Law of Aug. 8, 1924, § 9).

73. The term "country of origin" denotes the country outside of which a refugee is staying owing to fear of persecution. As far as refugees formally possessing a nationality are concerned, it means the same as "country of nationality." It comprises the terms "country of nationality" and "country of former habitual residence" used in para. 6(A)(ii) of the UNHCR Statute, supra note 5, and art.1(A)(2) of the Convention on Status of Refugees, supra note 4.

74. For example:

nationality has had general relevance in the law of the United Kingdom in connection only with the enjoyment of political rights, the extent of criminal jurisdiction, the right of residence within the dominions of the Crown, the right to practise certain callings, and the right to own certain categories of property-in modern days, British ships, formerly English land.

Parry, The Duty to Recognise Foreign Nationality Laws, 19 ZEITSCHRIFT FÜR AUSLÄNDISCHES OFFENTLICHES RECHT 337, 338-39 (1958) (citations omitted).

75. Apart from these municipal or domestic effects, the bond of nationality normally also has certain effects in international law. See infra text accompanying notes 77-91. See also P. WeIS, supra note 29, at 31-35; H. VAN PANHUYS, THE ROLE OF NATIONALITY IN INTERNATIONAL LAW 24-31 (1959).

76. See 1 L. OPPENHEIM \& H. LAUTERPACHT, supra note 15, at 645-46; P. Weis, supra note 29 , at $35-60$.

77. U.S. v. Mex., United States and Mexican Claims Comm'n 5, 4 R. Int'1 Arb. Awards 805 (1931).

78. Id. at 811 . 
tion, Commissioner Nielsen's statement gives the general rule that applies in the vast majority of cases where states exercise diplomatic or consular protection. ${ }^{79}$

The duty of a state to readmit one of its nationals at the request of another state ${ }^{80}$ is a corollary to the right of protection. For example, in Young v. Bundesrepublik Deutschland, ${ }^{81}$ the appellants, refugees from the People's Republic of China, had been given passports in Taiwan from the government of the Republic of China on Taiwan. However, those passports did not entitle the holders to enter Taiwan. The court found that the appellants did not enjoy the full protection of that government as outlined in the Convention on the Status of Refugees, and were thus entitled to refugee status. ${ }^{82}$

Two approaches to determining whether a person is a national of a state have emerged. One approach defines a national in terms of legal relations between states, as a person to whom the state possesses the right of protection and owes the duty of admission with respect to other states. ${ }^{83}$ The American commissioner in Laurent's Case ${ }^{84}$ reflected this view when he stated that "we are not to look to the Statutes of England for the definition of the term subjects, but to the settled practice and usages of nations."85 This internationally-based definition creates a risk of circular reasoning blurring the issues. If the right of protection does not apply to a given person, then that person is, by definition, not a "national" of the state in question.

The second approach, applied by the International Court of Justice in the Nottebohm Case, ${ }^{86}$ defines the term "nationality" with reference to a state's domestic law. This usage also conforms to the terminology used

79. The rule laid down by Commissioner Nielsen "reflects the facts but imperfectly." Parry, Some Considerations upon the Protection of Individuals in International Law, 90 RECUEIL DES COURS 653, 704 (1956); H. VAN PANHUYS, supra note 75, at 204.

80. See P. WEIS, supra note 29 , at $49-60$.

81. BVerwG IC 138.60, Mar. 23, 1964, cited in 1 A. GRAHL-MADSEN, supra note 27, at $191-92,260$.

82. See supra note 4. See also 1 A. GRAHL-MADSEN, supra note 27, at 191.

83. So at least it seems in P. WEIS, supra note 29, at 61:

Nationality in the sense of international law is a technical term denoting the allocation of individuals, termed nationals, to a specific State-the State of nationality-as members of that State, a relationship which confers upon the State of nationality the above-mentioned rights and duties in relation to other States.

On the other hand, Weis does not consider proteges and alien seamen to be nationals, although they may enjoy diplomatic protection. Id. at 42-44.

84. U.S. v. Gr. Brit., United States and Great Britain Comm'n for the Settlement of Claims, Rep. of Decisions 120 (1856).

85. Id. at 144 (emphasis in original).

86. 1955 I.C.J. 4, 20-21 (Second Phase Judgment of Apr. 6). 
in the Convention on Stateless Persons. ${ }^{87}$ Therefore, nationality is defined in domestic terms as an offshoot of municipal law and in international terms as conferring the right of protection ${ }^{88}$ and the duty of admission. ${ }^{89}$

The right of protection and the duty of admission pertain to certain categories of persons and not to others. By examining the concept of nationals as defined by states, an understanding of more marginal groups can evolve-groups like "protected persons" or "protégés,"90 American Indians, "Germans" as defined by article 116(1) of the 1949 German Grundgesetz, ${ }^{91}$ ships' crews, resident stateless persons, and, of central importance for the present study, various categories of refugees and displaced persons.

\section{B. The Right of States to Protect Individuals}

The right of a state to protect a person has as its corollary the obligation on the part of other states to accept such protection as lawful. This right and accompanying obligation extend beyond the protection of citizens, to certain classes of individuals who are not citizens of the protecting state. For example, this includes the well-known class of "British protected persons."92 Moreover, a flag state may protect a ship's crew irrespective of the nationality of individual crew members. ${ }^{93}$ On the other hand, residence or even domicile in the territory of a given state does not, as international law stands today, independently bestow any right of protection. ${ }^{94}$ Stateless persons do not normally enjoy the diplomatic or consular protection of the state in which they reside, except in those rare instances where they are accorded protection as mem-

87. See Convention on Stateless Persons, supra note 28, art. 1(1).

88. See C. Parry, Nationality and Citizenship Laws of the Commonwealth AND OF THE REPUBLIC OF IRELAND 11 (1957).

89. See generally P. WEIS, supra note 29.

90. See 1 L. OPPENHEIM \& H. LAUTERPACHT, supra note 15, at 646-47.

91. See 1 A. GRAHL-MADSEN, supra note 27, at 267-69.

92. See G. SCHWARZENBERGER, INTERNATIONAL LAW 130-31 (1957); see also L. LEE, Consular LaW and Practice 117-18 (1961).

93. See P. WeIs, supra note 29, at 43; see also R. BARBIER, L'INTERVENTION, DIPLOMA-

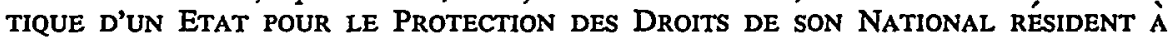
L'ETRANGER 98 (1935); E. BORCHARD, supra note 2, at 475-78; and the critical view expressed in $1 \mathrm{G}$. SCHWARZENBERGER, supra note 92, at 593-94. See also Case of the S.S. Lotus (Fr. v. Turk.), 1927 P.C.I.J., ser. A, No. 10 (Judgment of Sept. 7).

94. See E. BorChaRd, supra note 2, at 555-59; C. EAGLETON, THE RESPONSIBILITY of STATES IN INTERNATIONAL LAW 269 (1928); H. EEK, OM FRÄMLINGSKAP 101-02 (1955); 3 J. MoORe, A Digest of InTERnational LAW 276-82, 757-71, 790-95 (1906); C. PARry, supra note 88, at 699 . 
bers of ships' crews or of armed forces travelling abroad..$^{95}$ The ability of a citizen to forfeit his right to be protected, and the possibility of a state forfeiting its right to protect one of its nationals through expatriation or by waiver of international reclamation, ${ }^{96}$ remain contentious issues.

Even the possession of nationality does not guarantee that a state may exercise its protection. For instance, in cases of dual or multiple nationality, traditionally only one of the states whose nationality the individual possesses may extend protection, while the others may not. In the Nottebohm Case, ${ }^{97}$ the International Court of Justice stressed that nationality acquired through naturalization need only be recognized by other states if "the legal bond of nationality accord with the individual's genuine connection with the State."98 The Court subscribed to the theory that "nationality is a legal bond having as its basis a social fact of attachment, a genuine connection of existence, interests and sentiments, together with the existence of reciprocal rights and duties." Nationality only entitles a "State to exercise protection vis-à-vis another State, if it constitutes a translation into juridical terms of the individual's connection with the State." 99 The Court applied this theory to a case of nationality acquired by naturalization, ${ }^{100}$ but the theory may be capable of broader application.

\section{The Right of States to Protect Exiled Nationals: The Traditional View}

A state may not impose its nationality on aliens living in its territory against their will, thereby robbing their country of origin of its right of protection. A state may, however, impose its nationality on foreigners who accept certain official or governmental positions, as well as on persons who marry its nationals. These aliens either lose their original nationality or become dual nationals. In both cases, they become subject to the rule expressed in the Convention on Certain Questions Relating to the Conflict of Nationality Laws, which requires that "[a] State may not

95. See H. VAN PANhuYs, supra note 75, at 72; U.N. Economic and Social Council, A Study of Statelessness 32-33, U.N. Doc. E/1112 (1949); R. BARBIER, supra note 93, at 84. Note that protection of members of armed forces may be viewed from the perspective of state immunity.

96. See C. EAGLETon, supra note 94, at 168 (discussion of "Calvo clauses").

97. Liecht. v. Guat., 1953 I.C.J. 7 (Order of Mar. 21); 1955 I.C.J. 4 (Second Phase Judgment of Apr. 6).

98. 1955 I.C.J. at 23.

99. Id.

100. Id. at $24-26$. 
afford diplomatic protection to one of its nationals against a State whose nationality such person also possesses."101

Prolonged residence in a foreign country may deprive an individual of the "genuine connection of existence, interests and sentiments" to which the International Court of Justice referred in the Nottebohm Case. ${ }^{102}$ This is particularly true in the case of persons born abroad who have never resided in, nor perhaps even visited, the country of which they are nationals. For this reason, the nationality laws of certain states provide for the forfeiture of nationality of that state if the person fails to visit for a given number of years or when he reaches a certain age. However, notwithstanding such provisions, most states have been reluctant to give up their right to protect nationals even when these nationals have resided abroad for many years.

Nottebohm expressed the traditionally held position that "by taking up the case of one of its subjects and by resorting to diplomatic action or international judicial proceedings on his behalf, a State is in reality asserting its own rights-its right to ensure, in the person of its subjects, respect for the rules of international law." 103 According to this theory, it would seem obvious that a national may not deny a state its right of protection by a waiver of "international reclamation." Yet denying the national the right to waive protection may have dangerous repercussions on the individual involved. Hilding Eek describes incidents of aliens arriving in Sweden and asking for asylum, whereupon their country of origin, attempting to force repatriation, took action vis-à-vis the Swedish police and immigration authorities in order to "protect" the refugees. Under current practice, such action is usually fruitless, causing the asylum-seeker no inconvenience. Eek argues, however, that because the right of protection-jus protectionis-regulates only the relationship between states, the desires of individuals should, in principle, be irrelevant. $\mathrm{He}$ concludes that intervention by the state of a refugee's nationality on his behalf cannot be rejected as illegitimate under international law. ${ }^{104}$

Walter Schätzel makes the same general argument, but modifies it with regard to states that have ratified the Convention on the Status of Refugees, because these states "have thus recognized the international status

101. Convention on Conflict of Nationality Laws, supra note 68, art. 4.

102. 1955 I.C.J. at 23.

103. 1955 I.C.J. at 24.

104. H. EEK, supra note 94 , at $67-68$, 70. In disregarding "the desires of individuals" ("individernas onskemal"), Eek overlooks the fact that the "desires" have become manifest by the seeking and granting of asylum or refugee status. 
of refugees."105 Schätzel's exception has some significance in cases where both the country of origin and the country of refuge are parties to the Convention. Yet it would be difficult to apply it between a party state and a non-party state. Nonetheless, because the "international status of refugees" has its roots in general international law, a state's status as a party to the Convention should not be determinative of the state's right to provide protection.

Eek's and Schätzel's argument imperfectly restates the position of international law. By accepting public office in a foreign land, by marrying a foreigner, or by applying for or consenting to naturalization by another state, an individual frustrates or even terminates the right of protection of his country of origin. This is especially true when the individual acquires a new nationality, either automatically, by operation of law, or as a result of a governmental act. Similarly, an application for asylum or refugee status is not merely an expression of a desire, but is a definite legal step that may result in the granting of asylum or refugee status. If granted, such status resembles acquisition of a new nationality. Under these circumstances, Eek's and Schätzel's lines of reasoning lose their persuasiveness because their distinctions lose relevance.

Luke Lee discusses a state's right to deny the right of protection to a home state when a national wishes to waive that protection. He expresses the view that "States are generally loath to see aliens subjected to involuntary protection by consuls . . . . Thus, where consuls or other officials of the sending State have concerned themselves with reluctant nationals . . . their assertion of jurisdiction has frequently met with rebuffs from the receiving States." 106 In this context, Lee mentions the following provision of the Third Protocol of Signature to the United Kingdom-Swedish Consular Convention (1952):

The High Contracting Parties wish to place on record that, in their view, it is within the discretion of any state not to recognize the right of a consular officer of another state to act on behalf of, or otherwise concern himself with any national of the latter state who has become a political refugee. ${ }^{107}$

105. See W. SCHÄTZEL \& T. VeITER, HANDBUCH DEs INTERNATIONALEN FLÜCHTLINGSRECHTS 137 (1960).

106. L. Lee, supra note 92, at 120.

107. U.N. Doc. A/CONF.25/13/Add.1, quoted in L. LEE, supra note 92, at 120. See also Grahl-Madsen, Wiener-Konvensjonen om Konsulaere forbindelser av 24 April 1963, 34 NORDISK TIDSSKRIFT FOR INTERNATIONAL RET 301, 308-309 (1964); 1 E. DE VATTEL, LE DROIT DES GENS OU PRINCIPES DE LA LOI NATURELLE, APPLIQUES A LA CONDUITE ET AUX AFFAIRES DES NATIONS ET DES SOUVERAINS chap. XIX, § 226 (London 1758). 
This rule is reiterated in the Protocol to the European Convention on Consular Functions. ${ }^{108}$ The Vienna Convention on Consular Relations uses more guarded language. Article 36 stipulates only that a consul may not concern himself with a national of the sending state who has been arrested, imprisoned, or detained in the receiving state, and who expressly opposes such intervention. ${ }^{109}$

The Vienna Conference on Consular Relations did not resolve the problem of whether a state has the right to protect its nationals who have since become refugees. Instead, the matter was referred to "the appropriate organs of the United Nations." 110 Upon referral, it was determined that a state had no such right.111 Yet, neither the Economic and Social Council nor the General Assembly has dealt with this problem. Insofar as general international law is concerned, the issue remains unresolved. However, before squarely addressing the right of a state to protect nationals who have become refugees, a historical detour is necessary.

IV. The Evolution of the Concepts of Nationality and Diplomatic Protection

\section{A. Historical Perceptions of the Bond Between Sovereign and Individual}

Nationality in the modern sense, and formal nationality as a justification for state protection, are fairly recent conceptual developments. Their importance can best be understood from an historical perspective. In ancient Greece and Rome, citizenship was based on the principle of jus sanguinis; it was acquired at birth and depended on parentage. In feudal Europe, where territorial bonds were stronger than blood ties, the principle of $j u s$ soli-acquisition of nationality by place of birth-

108. Protocol to the European Convention on Consular Functions Concerning the Protection of Refugees, Dec. 11, 1967, Europ. T.S. No. 61, at 30.

109. See supra note 12. Several modern consular conventions provide that authorities of a receiving state shall not be obliged to return a seaman to a ship if "there is reasonable ground for believing that his life or liberty will be endangered, for reasons of race, nationality, political opinion or religion, in any country to which the vessel is likely to go." Consular Convention, Feb. 22, 1951, United Kingdom-Norway, art. 26(5)(b)(ii), 326 U.N.T.S. 209, 246. See also L. LEE, supra note 92, at 94-96. This provision may, of course, be construed as a supplement to the rule of non-refoulement which prohibits the forcible return of a refugee to a country in which he risks persecution. See Convention on Status of Refugees, supra note 4, art. 33; 2 A. GRAHL-MADSEN, supra note 1, at 93-98. The fact that this provision is found in a consular convention suggests a certain limitation as to the right of a consul, and hence of a sending state, to concern itself with crew members, including nationals of the sending state, who claim to be refugees.

110. Grahl-Madsen, supra note 107, at 308 ("de kompetente organer innen De Forente Nasjoner").

111. Id. 
emerged as the determinant of citizenship. As the feudal system in Europe broke down, residence became the single most important factor in determining the relationship between the individual and the state.112

Developments within the United Kingdom took a somewhat different turn. In England, birth "within the allegiance" of the Crown was long considered the distinguishing characteristic of subjects as opposed to aliens. ${ }^{113}$ At the same time, the British also developed the doctrine of "perpetual allegiance,"114 which made them reluctant to assimilate aliens. Parliament eventually won a struggle with the Crown for control over the naturalization process, and a naturalization case appears in the Rolls of Parliament as early as 1295 , followed by many more over the centuries. ${ }^{115}$ The courts upheld the requirement that one be a naturalborn British subject in order to enjoy certain civil rights such as the right to hold land. ${ }^{116}$ In this context, the English doctrine of perpetual allegiance was closely linked to the concept of domicile, particularly in its emphasis on the domicile of origin. ${ }^{117}$ Yet domicile has never been the legal basis of British nationality. ${ }^{118}$ The development of the concept of

112. In Norway and the free cities of continental Europe which lacked a feudal system, habitual residence formed the basic link between the individual and the res publica. Thus, King Christian V's Norwegian Code stipulated that anyone who lived or owned a residence within the King's realms and lands, but no others, were the King's subjects and owed him allegiance. Kong Christian Den Femtis Norske Lov, Book I, chap. 1, art. 5 (1687), 1682-1957 NORGES LOVER 3. The Norwegian Constitution, the oldest written European constitution still in force, used the terms "subject of the State" ("Statens Undersaat"). See, e.g., GruNDLov $\S 92$ (Nor. 1814). This term was chosen because the term "the King's subject" would also denote inhabitants of Denmark and of the duchies of Slesvig, Holstein and Lauenburg. "Norwegian citizen" has been used since May 17, 1814, to refer to persons residing in the country, with the following limitations on the rights of citizenship: the right to vote is subject to five years residence $(\S 50)$; the right to be appointed to public office is reserved for natural-born citizens, persons who have lived in the country for ten years, or persons naturalized by the Storting (Parliament) ( $(92)$; and the right to be elected member of the Storting requires ten years residence $(\S 61)$.

The United States and Great Britain similarly limit the rights of citizens based on residence; the corresponding provisions of the United States Constitution, art. I, § 2, cl. 2, and art. I, § 3, cl. 3, stipulate that a Representative or a Senator must have been a citizen of the United States for seven or nine years, respectively. The British rule, absent a written constitution, holds that naturalization is the prerogative of Parliament. Residence remained the basis for Norwegian nationality until 1888 , when birth became as important as residence. See Law Relating to Norwegian State-Citizenship etc., Apr. 21, 1888, in 1814-1953 COMPILATION OF NoRWEGIAN LAwS Erc. 29 (1956).

113. See C. PARRY, supra note 88, at 30-34. Allegiance and territorial jurisdiction were not completely coextensive.

114. Id. at $32-34,78$.

115. Id. at $34-40$.

116. This is demonstrated by Calvin's Case, 2 St. Tr. 559 (1608), cited in C. PARRY, supra note 88 , at 5-7.

117. C. PARRY, supra note 88 , at 4 n.6.

118. Cf. id. at 4 ("In common law countries, of course, civil status has at no time been made dependent upon nationality."). 
nationality in the British Isles thus differs from that in continental European countries.

\section{B. The Beginnings of Nationality Legislation}

The trend toward nationality in the modern sense started in the young and expansive American states. The Articles of Confederation contained the interesting provision that "the free inhabitants of each of these States, paupers, vagabonds and fugitives from justice excepted, shall be entitled to all the privileges and immunities of free citizens in the several States." 119 This provision clearly implies that residence was considered sufficient for a claim to U.S. citizenship. Nevertheless, the states continued to follow a practice developed under British colonial rule of passing naturalization laws and granting naturalization effective only in the particular colony in question. ${ }^{120}$ James Madison strongly criticized article IV on the basis that it made possible a situation where "in one State, residence for a short term confirms all the rights of citizenship; in another, qualifications of greater importance are required."121 For this reason, the 1787 Constitution gave Congress the power "to establish a uniform Rule of Naturalization."122 With the passing of the first Naturalization Act in 1790, the foundation was laid for the formalization of U.S. citizenship status based on a set period of residence. ${ }^{123}$

119. ART. OF CONFED. art. 4 (1776).

120. See generally C. PARRY, supra note 88, at 439-52, 523-33, 606-12, 657-70, 746-50, 788-97, 836-57, 883-89, 925-43 (nationality laws of various Commonwealth countries).

121. The Federalist No. 42, at 291-92 (J. Madison) (M. Dunne ed. 1901).

122. U.S. CONST. art. I, \& 8, cl. 4. A rule similar to the one in article IV of the Articles of Confederation was included in the Constitution: "The Citizens of each State shall be entitled to all Privileges and Immunities of Citizens in the several States." Id. art. IV, \& 2, cl. 1. It is interesting to note that the word "inhabitants" used in the Articles of Confederation has been superseded by the word "citizens." Interesting also is U.S. CoNST. art. I, $\S 9$, cl. 1: "The Migration or Importation of such Persons as any of the States now existing shall think proper to admit, shall not be prohibited by the Congress prior to the Year one thousand eight hundred and eight, but a Tax or duty may be imposed on such Importation, not exceeding ten dollars for every Person."

123. An Act to Establish an Uniform Rule of Naturalization, 1 Stat. III (1790). The act laid down the rule, subject to certain qualifications, "[ $[$ ] hat any alien, being a free white person, who shall have resided within the limits and under the jurisdiction of the United States for the term of two years, may be admitted to become a citizen thereof, on application to any common law court of record . . . ." Id. It is interesting to note that chapter II of the same statute, approved on March 1,1790, provided for the enumeration of the inhabitants of the United States. 1 Stat. II (1790). The fourteenth amendment to the Constitution, which entered into force on July 28,1868 , contained the provision that "All persons born or naturalized in the United States, and subject to the jurisdiction thereof, are citizens of the United States and of the States wherein they reside." It is generally agreed, however, that the amendment only stated the existing law, as far as the principle of jus soli is concerned, and that its primary purpose was to admit blacks to citizenship. See C. GETTYS, THE LAW OF CrTIZENSHIP IN THE UNITED STATES 11-12 (1934). 
In Europe, two different approaches were taken in the late eighteenth and early nineteenth centuries to defining citizenship rights. In some monarchies, only natural-born subjects and assimilated persons had the right to hold public office. ${ }^{124}$ Countries more heavily influenced by the American and French revolutions created additional regulations governing membership in the political community. In passing its civil code, France became the first major European country to supplement the principle of residence by establishing jus sanguinis as an additional basis for citizenship. ${ }^{125}$ The French enactments were a notable exception to the continental European rule. Residence remained the basis for nationality in continental Europe until the middle of the nineteenth century, and even later than that in Denmark, Norway, and Sweden. ${ }^{126}$

124. Typical of nationality laws in this category is a law signed on January 15,1776 by King Christian VII of Denmark-Norway, entitled The Law of Indigenousness, according to which "appointment to public office in his majesty's realms and lands is reserved for naturalborn subjects and persons assimilated to them." ("Indfyods-Retten, hvorefter Adgang til Embeder $i$ Hans Majestaets Riger og Lande forbeholdes alene de indfoodte Undersaatter, og dem, som derved lige agtes.") KOngeriget Danmarks Love 100 (H. Federspiel ed. 1910). The law drew a distinction between natural-born subjects and others, but only with regard to appointment to public office. While the conditions for naturalization were very strict, non-naturalized immigrants were also considered to be the King's subjects. Their children born within "The King's Realms and Lands" were full-fledged natural-born subjects under article 9 of the Law. The right of indigenousness applied to all persons born in the Kingdoms of Denmark and Norway, which also entailed the Faroes, Iceland, Greenland, and the Danish West-Indian Islands, as well as the duchies of Slesvig, Holstein and Lauenburg, provided only that the territory belonged to the monarchy. It applied also to children of subjects who were outside the territory on journeys or in the King's service.

125. While the French Constitution of September 14, 1791 had defined French citizenship on the basis of $j u s$ soli alone, the civil code completely changed those provisions. CODE CIVIL [C. Crv.], Code de la Nationalité arts. 17, 19, 44 (1981). For a long time, certain Italian cities had rules similarly regulating the possession of citizenship. Rules establishing a Helvetian citizenship were included in the Constitution of the Helvetian Republic, imposed on the Swiss Cantons in 1798, but they lost their importance as the Helvetian Republic collapsed. In France, the civil code was followed by a Decree of March 12, 1809 which instituted a naturalization procedure. See R. Flournoy \& M. HudSON, Nationality Laws 241-42 (1929).

126. In tracing the historical developments, dates are sufficient to tell the tale. The principle of $j u s$ sanguinis was contained in $\S 28$ of the Austrian Civil Code, (Allgemeines Bürgerliches Gesetzbuch of 1811 [hereinafter cited as ABGB]), but $\S 29$ stated that Austrian nationality was acquired by 10 years of residence in the country, by appointment to public office, or by the commencement of a business that necessitated the habitual residence in the country. See ABGB $\S \S 30,32$. Sections $29-32$ were amended by laws Nr. 108/1860 and Nr. 285/1925. The Austrian Civil Code was followed by similar enactments in the Norwegian Constitution of 1814, $\S 92$, and the Bavarian Edikt über das Indigenat (1818), reprinted in $\mathrm{R}$. Piloty \& C. Sutner, Die Verfallungsurkunde des Königreichs Bayern (1907).

A new wave of nationality legislation occurred about twenty years later. Nationality in the Netherlands was established in the "Bürgerlijk Wetboek" (1838). The Belgian Constitution of 1831 re-established the civil code. Nationality laws for certain classes were passed in 1835 and 1839. See R. FlourNoY \& M. HudSON, supra note 125, at 27. With regard to the Netherlands, see id. at 440. Prussia enacted the Gesetz über den Erwerbung und den Verlust der Eigenschaft als preussischer Unterthan (1842), GESETZ-SAMMLUNG FÜR DIE KöNIGLICHEN PREUSSISCHEN STAATEN, No. 2319 (1843), the first law to provide for a separate official action as one condition for the release from nationality $(\$ \S 15-26)$. See W. SCHÄTZEL \& T. VEITER, 


\section{Development of Diplomatic Protection-Eighteenth Century to the Present}

The emergence of diplomatic protection of nationals as an important legal concept stems from both the revolutionary development of international travel and the passage of early nationality and naturalization laws. It gained considerable momentum with the negotiation of the Jay Treaty ${ }^{127}$ between the United Kingdom and the United States. When continental European states in the eighteenth and the nineteenth centuries protected their nationals, they protected persons habitually residing in the territory of the claimant state. This practice may explain why "a certain hesitation was formerly shown as to whether the basis of the right of protection was not domicile rather than nationality."128 Even in British and American protection practice, residence played a major role. In 1844, the Queen's Advocate advised the government that the United Kingdom had the right to protect a foreign-born, non-naturalized merchant who had married an English woman and fathered children born in England, against the government of a foreign state that was not his country of origin. ${ }^{129}$ The United States-British Claims Commission of 1853 also made noteworthy decisions along these lines. ${ }^{130}$ The Com-

supra note 105 , at 133 . The first law on German federal nationality to have practical implications was the North-German Federal Gesetz über den Erwerb and Verlust der Reichs-und Staats-angehörigkeit (1870), modelled on the Prussian law of 1842 and, like its forerunner, based on the principle of jus sanguinis. Russian nationality was regulated in a law of 1864 , and Italian nationality in the Code of 1865 , CoDICE CiviLE [C. c.] art. 4 . In 1867 the Austrian Civil Code was amended to tighten considerably the rules for acquisition and loss of Austrian nationality. The first British naturalization act was passed in 1844; a new one appeared in 1870. See C. PARRY, supra note 88, at 65-71.

In 1888 Norway passed its first nationality law which substituted jus sanguinis for residence. The degree of foreign influence on the Norwegian Nationality Act of 1888 is evident in its reintroduction of the term "subject" into Norwegian nationality law, as though this were a recognized legal term: "A Norwegian citizen is a Norwegian subject." Law Relating to Norwegian State-Citizenship etc., supra note 112, § 7, para. 3. Also, "[t]hose inhabitants of the country not possessing the rights of Norwegian state-citizens are not Norwegian subjects." Id. § 8, para. 1. For details about the law, see E. DoNs, NORSK STATSBORGERrETT 26-28 (1947); E. HAMBRo, NORSK FREMMEDRETT 72-79 (1950). Laws similar in scope were passed in Scandinavian countries, including Sweden, in the late nineteenth century, see E. HAMBRo, supra, at 27-28.

127. Treaty of Amity, Commerce and Navigation, Nov. 19, 1794, (United States-United Kingdom), 8 Stat. 116, T.S. No. 105. Under the treaty, each side agreed to compensate nationals of the opposite country, pursuant to claims made to a joint claims commission, for losses suffered during the war. Id. arts. VI-VII.

128. C. PARRY, supra note 88, at 12. It may also explain Earl Russell's instruction to Sir J. Crampton of July 9, 1862, 25 PARLIAMENTARY PAPERS 696 (1868-69), which in that case would not appear as exceptional as it otherwise might.

129. Report of the Queen's Advocate (May 15, 1844) (F.O. 83/2341).

130. Cases include Laurent's Case (U.S. v. Gr. Brit.), United States and Great Britain Comm'n for the Settlement of Claims, Rep. of Decisions 120 (1856); Uhde Case, id. at 436; McCalmont, Greaves \& Co. Case, id. at 339. 
mission determined that British subjects domiciled in Mexico were to be regarded as nationals of Mexico and therefore could not present their claims to the Commission. In this way, the Commission responded to the American fear of adopting the British concept of perpetual allegiance, according to which numerous American citizens would have been considered British subjects. Instead of refusing jurisdiction in cases of dual nationality, ${ }^{131}$ the Commission chose to make residence the deciding factor. ${ }^{132}$

In the 1860's, however, the major continental European states followed the French example and abandoned residence as a basis for nationality. This period represents the turning point in the development of the modern concept of nationality. By 1870, the United Kingdom finally abandoned the doctrine of perpetual allegiance. ${ }^{133}$ By 1871, the AngloAmerican Claims Commission finally rejected the idea that a country's right of protection depended upon the residence of the injured person. ${ }^{134}$ Since that time, formal nationality and not residence has been the standard justification for diplomatic protection.

Despite official changes in policy in continental Europe, since persons residing in the various countries at the time of promulgation of the new laws were normally recognized as citizens, a time lag occurred before any practical difference between the concept of residence and that of nationality emerged. ${ }^{135}$ As time passed and the number of migrants increased, the distinction between persons residing in the country and persons possessing formal citizenship or nationality increased in significance.

131. Such a course of action might have proved difficult in view of the fact that American citizens of British origin were presenting claims against the United Kingdom.

132. The famous Thrasher Case, see $3 \mathrm{~J}$. MOORE, supra note 94, at 817-20, and the Koszta Case, id. at 821-54, reflect this development. See also E. BorCHARD, supra note 2, at 570-72. These cases occurred at about the same time and raised the question whether domicile alone or together with a declaration of intent to become a citizen was of importance for the right of protection.

133. See British Naturalization Act of 1870,33 Vict., ch. 14. Two years earlier, citizenship had been addressed in the fourteenth amendment to the United States Constitution, supra note 123. In 1868, the United States also passed a new Naturalization Act that expressly permitted expatriation. See An Act Concerning the Rights of American Citizens in Foreign States, ch. 249, 15 Stat. 223 (1868).

134. This was the case of Arthur Barclay, Report of the Proceedings and Awards of the Mixed Commission on British and American Claims, 75 ParLIAMENTARY PAPERs 25 (1874). For a discussion of the importance of domicile with regard to protection in Anglo-American practice, see C. PARRY, supra note 88, at 11-17.

135. For example, the Law Relating to Norwegian State-Citizenship etc., supra note 112, provided:

Any foreign person domiciled in the Kingdom who, without being entered in the Register, shall claim to have acquired the rights of a Norwegian state-citizen at the time when the present Law comes into force, must, in order to secure such right, apply to the Authorities, within one year after the said term. 
The consequences of the change in the concept of nationality emerged slowly with regard to public international law as well. Certain protection practices, more in keeping with the former European concept of nationality based on residence than with the new concept of nationality based on more formal legal criteria, continued for some time. ${ }^{136}$ For example, the practice of protecting seamen sailing under the flag of the state in question, regardless of their nationality, wass strongly advocated in a letter of October 26, 1796 from the U.S. Secretary of State to the U.S. Ambassador to England. The Secretary concluded: "The measure was natural and necessary; and hence was practiced by the consuls of other nations as well as our own."137 Such protection has continued to be "natural and necessary" in the day-to-day intercourse between shipping and coastal countries. Thus, although the practice of protecting people with potentially stronger ties to the territory proper, but who have not been formally naturalized, has generally given way to modern protection practices, the practice of protecting people who have ties only to the ship, or to "extended territory," persists. 138

States have also tended to deny protection to certain categories of nationals living outside their country of nationality when it is reasonable to believe that they have no intention of returning and taking up the duties of citizenship, and that, consequently, their nationality is only nominal. ${ }^{139}$ In 1873, the U.S. Secretary of State wrote to the U.S. Ambassa-

136. A right of protection is not something inherent in or deducible from "nationality," but rather is the result of an evolution. Van Panhuys, supra note 75, is correct when he criticizes the judgment in the Reparations Case, Reparations for Injuries Suffered in the Service of the United Nations, 1949 I.C.J. 174 (Advisory Opinion of Apr. 11), on the ground that protection there is coupled with allegiance. Van Panhuys is certainly right when he states that "from the standpoint of international law, the right to protect does not exclusively result from allegiance but is based on customary law that has developed gradually and to which all sorts of circumstances . . . have contributed . . ." H. VAN PANHUYs, supra note 75, at 204.

137. 3 J. MOORE, supra note 94, § 484. The U.S. Secretary of State in 1796 was Col. Timothy Pickering. See also E. BoRCHARD, supra note 2, §206.

138. See H. VAN PanhuYs, supra note 75, at 73: "It may seem a little curious that in respect of aliens on what has been termed a floating part of the State's territory the rights of the State are wider than in respect of aliens on its territory proper, including persons permanently domiciled there." Seen against the historical background outlined here, the protection of seamen does not seem as odd as Van Panhuys suggests.

139. See generally 3 J. MOORE, supra note $94, \S 474$ (discussion of loss of right to national protection); E. BorCHARD, supra note 2, § 325. Parry sums up the situation: "A survey such as this of the actual practice of States should persuade us that such a rule as that a State may protect any one of its nationals unless he happens to be also a national of the respondent State reflects the facts but imperfectly." Parry, supra note 79, at 704. Raestad expresses the view that those persons who have been naturalized abroad, and who by leaving their home country lost their original citizenship, would be excluded from protection when returning to their country of origin. According to Raestad, protection would also be denied to citizens residing abroad who have declared their intent to become naturalized in their country of residence or who have hidden the fact that they are citizens of a country other than that of residence. 
dor to France that "[t]he duty of protection as toward the citizen, or the rights of its exercise as toward the foreign power, is not always correlative with the fact of citizenship." 140 In many senses, then, the traditional view of protection, based upon ties to one's residence, has prevailed to the present time. As pointed out by Parry, ${ }^{141}$ the reasoning of the International Court of Justice in the Nottebohm case should come as no surprise. ${ }^{142}$ This view may provide a basis for analyzing the right of the state of nominal nationality to protect its exile citizens.

\section{The Special Position of Refugees: Ending the State of Nationality's Right to Protection}

\section{A. The Irrelevance of a Refugee's Nationality of Origin}

Despite the emergence of the concept of formal nationality rather than residence or domicile as a basis for customary protection, states have seldom made claims to protect their exiled nationals in any beneficial manner. Rather, states from which refugees have fled have often stripped them of their nationality. ${ }^{143}$ Even those states that have not resorted to this measure have evinced little interest in the fates of these refugees. ${ }^{144}$ If states of nationality should express an interest in their departed citizens, valid reasons exist for denying the state of nationality the right to "protect" exiled nationals. Since the refugee has in a decisive manner broken his ties with the government of his home country, that government would most likely exercise "protection" not for the benefit of the refugee, but for its own purposes. Often the only reason for the "protection" will be to harass the government of the country of asylum. ${ }^{145}$ In such a case, intervention may amount to an abuse of the right of pro-

Raestad, Diplomatisk beskyttelse av landsmenn $i$ utlandet, 4 NORDISK TIDSSKRIFT FOR INTERNATIONAL RET 3, 20 (1933).

140. Letter from Mr. Hamilton Fish to Mr. E. B. Washburne (June 28, 1873), reprinted in Papers Relating to the Foreign Relations of the United States 256, 260 (1873). See also 3 J. MOORE, supra note 94 , § 474.

141. Parry, supra note 79, at 704-05.

142. This is so even if one criticizes the manner in which the Court applied the criterion of "the individual's genuine connection with the State" to the facts before it as a condition for real and effective nationality. Nottebohm Case (Liecht v. Guat.), 1955 I.C.J. 4, 23 (Second Phase Judgment of Apr. 6).

143. See Raestad, supra note 71 , at 185 ; W. SCHÄTZEL \& T. VEITER, supra note 105, at 132; Schätzel, De-facto-Staatsangehörigkeit und De-facto-Staatenlosigkeit, in VöLKERRECHT UND RECHTLICHES WeLtBILD 217, 220 (F. v.d. Heydte, S. Verosta, I. Seidl-Hohenveldern \& K. Zemanek eds. 1960).

144. W. SCHÄTZEL \& T. VEITER, supra note 105 , at 135.

145. Since the Second World War, several countries of origin have amended their nationality laws so that loss of nationality can only be brought about by formal release by competent authority, and such release is extremely difficult to obtain. This makes it more difficult for countries of asylum to resist this sort of pressure. 
tection. ${ }^{146}$ In addition, Eek is too optimistic when he states that intervention will not cause inconvenience to the refugees. ${ }^{147}$ As pointed out by Schätzel, intervention by the state of nationality "on behalf of" refugees may cause considerable hardship for the individuals involved, and recognition of the legitimacy of such intervention could create the impression that the asylum is imperfect. ${ }^{148}$

Furthermore, when a state grants asylum to a person, it permits him to enter and remain in the country without asking if he has a passport and thus without caring whether or not another country has a duty to take him back. This inattention to the duty of admission could reasonably be accompanied by the assertion that the country of origin has suspended its right of protection. In its Resolution on the Legal Status of Stateless Persons and Refugees, ${ }^{149}$ the Institut de Droit International asserted that a refugee who is still formally a national of his country of origin, but who has established his domicile or his habitual residence in another country, should enjoy the same civil and public rights as those enjoyed by stateless persons in that country. ${ }^{150}$ Similarly, a refugee who has lost his nationality could claim those civil and public rights that attached to his lost nationality in the case of a mass population displacement. ${ }^{151}$

The drafters of the Convention on the Status of Refugees were of the opinion that the formal nationality that some refugees possessed was ineffective, as the refugees could not in any way benefit from it. Consequently, the drafters felt that refugees should not be prejudiced by it. ${ }^{152}$ Equality of status among refugees, stateless persons, and nationals was expressed in a principle of non-discrimination on the basis of race, religion, and country of origin. ${ }^{153}$ Article 7, dealing with exemption from

146. See W. SCHÄTZEL \& T. VEITER, supra note 105, at 134-37. See also H. EEK, supra note 94, at 69, 72-73; L. LEE, supra note 92, at 120.

147. H. EEK, supra note 94 , at 70 .

148. W. SCHÄTZEL \& T. VEITER, supra note 105 , at 137.

149. Statut juridique des apatrides et des refugiés, Résolutions votées par l'Institut au cours de sa XLe session, reprinted in 2 ANNUAIRE DE L'INSTITUT DE DROIT INTERNATIONAL 292 (Session de Bruxelles, Apr. 1936).

150. Id. art. 9(2). In many instances the nationality of a refugee is uncertain or even unknown. Hence the notion of "de facto stateless persons." See Convention on Stateless Persons, supra note 28.

151. See Statut juridique des apatrides et des refugiés, supra note 149, art. 9.

152. Prof. Louis Henkin of Columbia University pointed out that in the case in question it was not only a matter of ensuring that discrimination would not be practiced against refugees as such, but also that the High Contracting Parties would not discriminate between the refugees themselves in applying the Convention or their domestic law. Some provision to that effect was important if the legal protection of refugees was to be ensured. U.N. Doc. E/ AC.32/SR.24, at 12 .

153. Convention on Status of Refugees, supra note 4, art. 3. Article 3 was proposed by the delegation of Belgium to the Ad Hoc Committee, see Ad Hoc Committee on Statelessness and Related Problems, U.N. Doc. E/AC.32/SR.24, at 11. 
reciprocity, further evidenced the fact that recipient states were expected to assimilate fully those refugees possessing a formal nationality along with those who were stateless. ${ }^{154}$ The principle of exemption from reciprocity and its bolstering arguments grew out of older instruments that wholly or largely dealt with stateless refugees. The fact that many current refugees are not de jure stateless was not raised as a challenge to the principle, and some participants even suggested that, if agreements of reciprocity existed between the state of nationality and the state of asylum, refugees could hardly invoke them. ${ }^{155}$ None of the drafters believed that a state granting asylum had an obligation, regardless of its enforceability by way of diplomatic intervention, to allow refugees to benefit from such agreements if they formally possessed the nationality of the other party to the agreement. ${ }^{156}$ Articles of the Convention on the Status of Refugees designed to exempt bona fide refugees from any detrimental effects due to their formally possessing their original nationality are evidence that the drafters of the Convention on the Status of Refugees considered such nationality ineffective. The drafters deemed the relationship between the country of nationality and the country of asylum utterly irrelevant to the treatment of refugees. ${ }^{157}$

The continuous non-exercise of a potential right to protect exiled nationals by states of origin over a protracted period of time has, therefore, created an expectation on the part of countries of asylum that such protection will not and may not be exercised. This expectation carries sufficient legal force that such a "right of protection" today can be said to be effectively obsolete. Another exception is thus created to the rule that nationality justifies protection. Indeed, to acknowledge such an exception is well in keeping with the "genuine connection" theory, focusing

154. Convention on the Status of Refugees, supra note 4, art. 7.

155. See H. EEK, supra note 94, at 185; E. JAHN, DER VöLKERRECHTLICHE SCHUTZ VON FLÜCHTLINGEN 12-13 (1955); G. SCHWARZENBERGER, supra note 92, at 73-74; A. Ross, A TEXTBOOK OF INTERNATIONAL LAW 110 (1977).

156. A rule for the exemption of refugees from reciprocity was first included in the Arrangement Relating to the Legal Status of Russian and Armenian Refugees, June 30, 1928, art. 4, 89 L.N.T.S. 53, 57, and subsequently in the Convention Relating to the International Status of Refugees, Oct. 28, 1933, art. 14, 159 L.N.T.S. 199, 209.

157. See supra note 4. The first sentence of article 8 was borrowed loosely from the Geneva Convention Relative to the Protection of Civilian Persons in Time of War, Aug. 12, 1949, art. 44,6 U.S.T. 3516, 3546, T.I.A.S. No. 3365, 75 U.N.T.S. 287, 316. The second sentence of the article, which facially seems incompatible with the general principle of the ineffectiveness of nationality in international law, as far as refugees are concerned, was initiated by the Swedish delegate to the 1951 Conference, but was strongly opposed by several other delegates. It was only included in order to prevent certain countries from having to file reservations with regard to article 8. The meaning of the second sentence of article 8 is that in the absence of legislative exemption, the contracting parties should honor the peculiar position of refugees who only formally possess nationality. In appropriate cases, such refugees should be granted exemption by means other than legislation. 
upon an individual's de facto ties and allegiance to a state which the International Court of Justice pronounced in Nottebohm.

\section{B. Reactivation of Nationality}

Although the state of nationality has no right to protect a refugee who has fled from it, its efforts to exercise control over the refugee may nonetheless cause such a refugee serious hardship. In particular, a refugee whose country tries to protect him may suffer discrimination by the country in which he is staying. 158 The refugee who has retained the nationality of his country of origin may thus be forced to choose between two evils. If he chooses to apply to his national state for protection and receives such protection, he automatically ceases to be considered a refugee. ${ }^{159}$ The country of residence is obliged to recognize the reactivation of the refugee's nationality and must allow the state of nationality to protect him. ${ }^{160}$

Reactivated nationality raises the issue of whether a right of protection may be exercised with retroactive effect. Can the state of nationality intervene and, in appropriate cases, claim reparation for acts committed or omitted while the person in question was considered a refugee or must the state of nationality claim reparation only for acts subsequent to actual reactivation? Through the inaction on the part of countries of nationality, countries of asylum have acquired a legally relevant expectation that refugees will not be protected and, consequently, that they cannot be protected. Countries of asylum and countries of nationality have traditionally considered their relationships with each other to be irrelevant to the treatment of refugees. ${ }^{161}$ Because states do not tend to take the national character of the individual refugees into account, no retroactive responsibility toward the state of nationality can arise out of the treatment accorded a refugee.

Provisions of the Refugee Convention and the UNHCR Statute create a specific problem in that a person may be considered a refugee if he is willing but unable to avail himself of the protection of his state of nationality. ${ }^{162}$ If a refugee remains consistently willing to avail himself of the protection of his country of nationality, and if he has filed an application

158. The same argument may, however, be advanced with regard to stateless persons, and even with regard to nationals living in their own country unprotected, in the international sense, against their own government.

159. Convention on Status of Refugees, supra note 4, art. 10(1). See also 2 A. GRAHLMADSEN, supra note 1 , at 379.

160. Such reactivation, though, is not to be considered naturalization.

161. See Convention on Status of Refugees, supra note 4, arts. 3, 7-9.

162. Id. art. 1(A)(2); UNHCR Statute, supra note 5, para. 6(B). 
to that effect in that country's embassy or consulate, the state of nationality may choose to extend such protection to the refugee by granting him a national passport and allowing him to return there. Until this happens, however, the person must be considered a refugee, ${ }^{163}$ and the country of asylum should be obliged to treat him as such. This obligation carries with it the corresponding right on the part of the country granting asylum to refuse intervention by the country of nationality on behalf of the refugee. ${ }^{164}$

A peculiar situation arises if a refugee registers at the consulate of the country of which he is a national and obtains a national passport without intending to renounce his refugee status. If the person still fears persecution and does not understand that obtaining a passport normally means availing oneself of the protection of the issuing state, it would obviously be difficult to withdraw refugee status on the basis of such a confused act. A refugee who happens to be in possession of a national passport at the time of becoming a refugee is not normally required to return or to surrender such passport, which remains prima facie proof of nationality but is no longer an instrument of protection. The same approach is justified with regard to a passport acquired after refugee status has been obtained, but without an understanding of the implications of the acquisition. The mere issuance of such a passport gives no title to protection. ${ }^{165}$ A refugee should lose his refugee status and regain his status as an alien possessing the effective nationality of the issuing country only if, with full knowledge of the consequences, he submits his passport to the authorities of his new country of residence and requests a visa so that he may continue his stay in that country as a national of his country of origin.

\section{The Role for Third States}

If a refugee leaves the country where he has been recognized as a refugee, any other state may rule independently on his eligibility as a refugee. If he is admitted to the territory of another state on the basis of a travel document, that state may, like the state issuing the document, refuse to recognize any protection by the nationality state. Consequently, it may

163. See 1 A. GRAHL-MADSEN, supra note 27, at 367-70.

164. Furthermore, protection extended to a refugee falling into this category should have no retroactive effect. Because of the refugee's willingness to accept protection, the state of nationality had the power to grant protection at an earlier date. It is hardly equitable that the country of asylum should be forced to allow the state of nationality to intervene merely because of the latter's hesitance in granting protection earlier.

165. The situation therefore parallels the issuance of a passport or the issuance of a travel document to a national who is also a national of the country in which the consulate is located. Convention on Status of Refugees, supra note 4, Schedule, para. 16. 
reject any intervention by the state of the refugee's nationality on his behalf. The country admitting the refugee may not even know the particular nationality of the refugee to whom it is extending its hospitality. The specimen travel document annexed to the Refugee Convention, for example, contains no reference to the holder's nationality. ${ }^{166}$ Thus, the admitting state enters into an international relationship only with the issuing state. On the other hand, if a refugee in possession of a national passport, issued by a competent authority of his country of nationality, is admitted to a third country on the strength of that document, it would be equitable for the third state to treat him in every respect as a national of the issuing state rather than as a refugee. If this creates hardship for the fleeing person, he can either apply for refugee status in the country where he finds himself, or he can proceed to another country where he will be given refugee status. Once a state recognizes a person admitted on a national passport as a bona fide refugee, it should be able to reject any intervention attempts by the state of the refugee's nationality. ${ }^{167}$

\section{Conclusion}

A modern view of international refugee law must recognize that a refugee's state of origin lacks any right to "protect" the refugee. This doctrine is both coherent and equitable. It is consistent with the generally accepted view that "such a rule as that a State may protect any one of its nationals unless he happens to be also a national of the respondent State reflects the facts but imperfectly."168 Furthermore, it advances the "genuine connection" concept professed by the International Court of Justice in the Nottebohm Case. The doctrine is based on the express manifestations of a refugee's will, the breaking of ties between him and his state of nationality, and his pursuit and attainment of asylum. Indeed, the theory emerges as a logical result of the link between a state's naturalization of a refugee and its granting of refugee status. A country of asylum can always legitimately naturalize the refugee ${ }^{169}$ and, on that basis, reject any claim of protection by the country of origin. ${ }^{170}$ The same right to resist

- 166. Id. Annex to Schedule.

167. This may apply even to an asylum-seeker whose refugee status has not yet been recognized.

168. See Parry, supra note 79, at 704.

169. P. WEIS, supra note 29, at 98; see also N. BAR-YAACOV, DUAL NATIONALITY 141-42 (1961).

170. See GRUNDGeSETz [GG] art. 116 (W. Ger.), according to which ethnic Germans expelled from Eastern Europe automatically become German citizens. Schätzel, supra note 143 , at 221, considers their status to be that of de facto nationals, and he comments that with the de facto nationality the old concept of nationality based on residence is revived. 
intervention by the state of nationality should, then, arise from the granting of asylum. ${ }^{171}$

The doctrine succeeds in bringing about a crucial balance between the right of protection and the duty of admission, the two most important concomitants of nationality in international law. ${ }^{172}$ The state of nationality, if it refuses to admit the national, effectively gives up its right to "protect" him in any way. Conversely, by granting asylum, a state would relieve the state of nationality of its duty to admit its national. As long as the national were recognized as a refugee, the state of refuge would possess the exclusive right of protection. Only by assuring both the refugee and his state of refuge that the state of origin has lost any right to act "on behalf" of its exiled national can international law assure that the refugee will find genuine protection in his place of asylum.

171. This doctrine may also serve to throw light on rules regarding protection of dual nationals in a third country. To explore that proposition, however, would go beyond the scope of this study. See e.g., P. WEIS, supra note 29, at 196-99; N. BAR-YAACOV, supra note 169, at 232 n. 68 .

172. See generally P. WEIS, supra note 29 , at 35-62. 